\title{
The importance of bioequivalence study: focus on clopidogrel
}

\author{
Arini Setiawati \\ Department of Pharmacology \& Therapeutics, Faculty of Medicine, University of Indonesia, Jakarta, Indonesia
}

\begin{abstract}
Abstrak
Studi bioekivalensi (BE) diperlukan untuk menunjukkan apakah suatu produk copy dapat menggantikan produk inovator. Tujuan makalah ini adalah untuk menjelaskan alasan melakukan studi BE, produk-produk utama yang memerlukan studi BE, serta desain dan pelaksanaan studi BE, dengan fokus pada klopidogrel. Semua produk generik klopidogrel di Indonesia telah ditunjukkan bioekivalen (BE) dengan produk inovatornya, Plavix ${ }^{\circledR}$, dan mereka mengandung bahan baku klopidogrel form 1 yang memenuhi persyaratan USP 30, 1997: kandungan enansiomer R tidak lebih dari 1\%. Bukti bahwa bioekivalen (BE) berarti ekivalen secara terapeutik (TE) juga ditunjukkan untuk obat-obat kardiovaskular. Klopidogrel mempunyai 2 bentuk polimorfik, form 1 dan form 2, yang mempunyai indikasi yang sama. Sedikitnya satu studi klopidogrel yang pivotal, CAPRIE, menggunakan klopidogrel form 1. Suatu kejadian aterotrombotik mungkin berhubungan dengan resistensi terhadap klopidogrel, yang terjadi pada sekitar 4 sampai 30\% pasien yang diobati dengan dosis klopidogrel yang biasa diberikan. (Med J Indones 2011; 20:149-53)
\end{abstract}

\begin{abstract}
Bioequivalence (BE) study is required to show whether a generic copy product can be interchangeable with the brand innovator product. The aim of this article is to provide the rationale for conducting BE studies, the main products requiring BE studies, the design and conduct of BE studies in general, with focus on clopidogrel. All of the clopidogrel generic products in Indonesia have been shown to be BE to the innovator product Plavix ${ }^{\circledR}$ and they contain API (active pharmaceutical ingredient) clopidogrel form 1 that complies with USP 30, 1997 requirements: the R-enantiomer content is not more than $1 \%$. A proof that bioequivalence (BE) means therapeutic equivalence (TE) is also provided for cardiovascular drugs. Clopidogrel has 2 polymorphic forms, form 1 and form 2, which have the same indications. At least one pivotal study of clopidogrel, CAPRIE, used clopidogrel form 1 . An atherothrombotic event may be associated with clopidogrel resistance, which occur in about 4 to $30 \%$ of patients treated with conventional doses of clopidogrel. (Med J Indones 2011; 20:149-53)
\end{abstract}

Key words: bioequivalent, clopidogrel

Health care costs continue to increase, and one important component that can be reduced substantially is drug cost. For this purpose, substitution of the expensive originator drugs with cheaper generic copies is required. Since the generic copies are intended to substitute the innovator products, the generic products should be therapeutically equivalent to the brand innovator products. Therapeutic equivalent (TE) can be reached when the generic copy is bioequivalent (BE) to the brand innovator product.

A clinical comparative study which shows therapeutic and side effects should beideal to show therapeutic equivalence, but often lack of clearly defined and measurable endpoints, and there is a high variability of the measured endpoint. Therefore, a very large sample size is required to conduct an equivalence trial (a negative trial) to show therapeutic equivalence between the 2 products. Clinical trials are not the optimum choice for comparisons of formulations with small differences. Thus, an alternative method should be developed, which is the pharmacokinetic approach. The advantage of this approach is that the endpoint is clearly defined, i.e. the plasma concentration of the drug, with lower variability, and therefore the studies are smaller and more powerful.

The plasma concentration of a drug, which is in equilibrium with its concentration in the receptor site, determines the number of drug molecules at the receptor site which produce the therapeutic effect. The plasma concentration of a drug is governed by the drug's absorption, distribution, metabolism, and excretion (ADME) of the active drug. The D, M, and E are constant within the same subject, therefore differences in the plasma concentration (= the therapeutic effect) are due to differences in the amount of drug absorbed, or in other words depends on the delivery of drug from its formulation. Thus, the therapeutic effect depends on the bioavailability (BA) of the drug product, and therefore bioequivalence means therapeutic equivalence.

Before discussing bioequivalent of a product, we will first discuss what is bioequivalence (BE), therapeutic equivalence (TE), main products requiring $\mathrm{BE}$, as well as design and conduct of BE studies in general.

What is bioequivalence $(\mathbf{B E})^{\mathbf{1}}$. There are some definitions.

Bioavailability (BA) is the amount of drug, in percentage of dose, which is absorbed and reaches the systemic circulation (bioavailable) in unchanged/active form. Bioequivalence (BE) is equivalence bioavailability of 2 drug products with pharmaceutical equivalence or pharmaceutical alternatives. 
Pharmaceutical equivalence is if both drug products contain the same amount of the same active substance in the same dosage forms.

Pharmaceutical alternatives if both drug products contain the same amount of active moiety but differ in the chemical form (salt, ester, etc.) or in the dosage from (tablet, capsule, etc.)

Therapeutic equivalence (TE) is equivalent therapeutic effect of 2 drug products.

\section{Products requiring BE studies ${ }^{1}$}

These are mainly (1) drugs with narrow margin of safety, e.g. digoxin, antiarrhythmics, anticoagulants, cytostatics, lithium, phenytoin, cyclosporine, sulphonylureas, theophylline; (2) critical use drugs, i.e. drugs indicated for serious conditions requiring assured therapeutic response, e.g. antiinfectives, cardiovascular drugs, antiepileptics, antiasthmatics; and (3) sustained or modified release products, due to the difficult formulation.

\section{Design and conduct of BE studies ${ }^{1}$}

Since BE studies are conducted in man (clinical studies), design and conduct of BE studies should follow Good Clinical Practice (GCP) principles. The study protocol should obtain ethical approval before starting the study, and informed consent should be obtained from each subject before screening the subject.

A BE study is a comparison of 2 formulations, i.e. the test product (the generic/copy product) versus the reference product (the innovator product), therefore the design of choice is a randomized 2-way cross-over study, in which the same subjects receive both drug products. Since every subject becomes his/her own control, this design is a very powerful study requiring a small number of subjects. The wash-out period is at least 5 times the elimination half-life of the measured analyte, to ensure that more than $95 \%$ of the first administered product has already been eliminated before giving the second product. BE studies are in general single dose studies, because they are generally more sensitive in assessing release of the drug substance from the drug product into the systemic circulation.

The subjects for BE studies are healthy volunteers (to minimize variability) of both sexes, aged 18 to 55 years with normal body weight, nonsmokers (preferably) or moderate smokers ( $<10$ sticks/day), and no history of alcohol or drug abuse. The number of subjects is minimally 12, but in general 18 to 24 subjects are required.

Sampling times are generally 12 to 18,1 at time zero (baseline), 2 to 3 before $\mathrm{C}_{\max }$ (maximal plasma concentration), 4 to 6 around $C_{\max }$ (to estimate $C_{\max }$ ), and 5 to 8 after $\mathrm{C}_{\max }$, until at least 3 times the plasma half-life to cover more than $80 \%$ of the absorption phase.
The bioanalytic part of BE studies should follow GLP (Good Laboratory Practice)principles. The bioanalytical methods used to measure the analyte in plasma/serum should be validated for accuracy, precision, specificity, sensitivity, and reproducibility. The measured analyte for BE studies is generally only the parent drug released from the dosage form, because concentration-time profile of the parent drug is more sensitive to changes in formulation than the metabolite.

The comparator or reference product in a BE study is the product intended to be substituted by the copy product, then in general it should be the innovator product in the respective country.

The BA (bioavailability) parameters to be compared in a BE study are (see Figure 1):

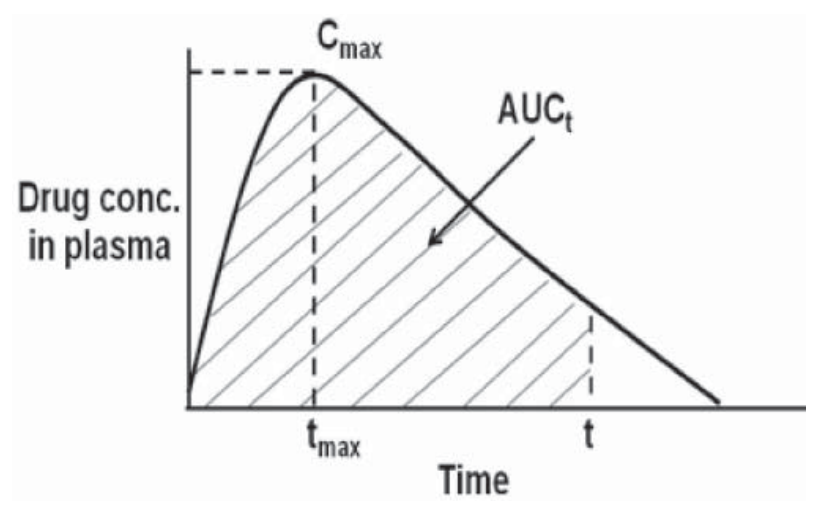

Figure 1. Drug concentration in plasma versus time. AUC (area under the plasma concentration versus time curve until the last observation time t); $A U C_{\text {inf }}$ (AUC until infinitive time); $C_{\max }$ (maximal plasma concentration); and $t_{\max }$ (time to reach $C_{\max }$ ). AUC represents extent of absorption, $t_{\max }$ rate of absorption, and $C_{\max }$ represents both extent and rate of absorption.

The criteria for BE between the test product $(\mathrm{T})$ and the reference product $(\mathrm{R})$ : if the $90 \%$ confidence interval of the T/R AUC and $\mathrm{C}_{\max }$ geometric mean ratios (GMRs) are within the range of $80-125 \%$ (in general).

\section{BE studies of clopidogrel generics}

Clopidogrel is a prodrug that must undergo hepatic metabolism to become the active metabolite. ${ }^{2}$ The active metabolite is highly unstable and thus difficult to measure. ${ }^{2}$ Therefore, the BE study of clopidogrel may be a pharmacokinetic study or a pharmacodynamic study. The pharmacokinetic BE study of clopidogrel is based on the measurement of clopidogrel parent compound (according to USFDA, 2003). The pharmacodynamic BE study of clopidogrel is based on the inhibition of ADP binding to its platelet membrane receptors, P2Y12, which causes platelet aggregation. ${ }^{2}$ 
Since the pharmacodynamic endpoint, the platelet aggregation, is highly variable, then the pharmacokinetic method is generally chosen.

Clopidogrel bisulphate has 2 enantiomers, ${ }^{4} \mathrm{~S}$ and $\mathrm{R}$, the $\mathrm{S}$-enantiomer is the active one, while the R-enantiomer is less active and poorly tolerated. The pharmacokinetic method should ideally measures the S-enantiomer by the enantiospecific assay. However, since the nonenantiospecific assay is still accepted for BE study ${ }^{1}$ all BE studies in Indonesia still use this kind of assay. Then, the percentage of R-enantiomer is based on the certificate of analysis (CoA) of the active pharmaceutical ingredient (API) from the supplier of the API. The clopidogrel generic products contain clopidogrel bisulfate form 1 , the patent of which has already expired in Indonesia since 2008, and this API complies with the USP 30 (2007) requirements: the R-enantiomer content is not more than $1 \%$ and the hydrolysis product is not more than $0.2 \%{ }^{6}$

Thus, BE studies of clopidogrel generics were performed by pharmacokinetic method based on the measurement of clopidogrel parent compound using non-enantiospecific assay. It was a randomized 2-way cross-over study with one-week wash-out period. The generic copy was compared to the innovator Plavix ${ }^{a}$. The study used $18-$ 24 healthy volunteers, each took a single dose of $75 \mathrm{mg}$ clopidogrel base in fasting condition. The results showed that all of the generic copies in Indonesia fulfilled the BE criteria: the $90 \%$ confidence interval of the generic/ innovator AUC and $\mathrm{C}_{\max }$ geometric mean ratios (GMRs) lied in the range of 80 to $125 \%$.

Not all clopidogrel products comply with the USP requirements. This has been shown by Gomez et al. ${ }^{8}$ who studied the purity of 18 product tablets containing clopidogrel generic copies. The USP $30(2007)^{5}$ requirements for clopidogrel tablets: the R-enantiomer is not more than $1.5 \%$, and the hydrolysis product not more than $1.2 \%$, while the total impurities not more than $2.5 \%$. From 18 products: 3 products (17\%) had hydrolysis product exceeding the USP limit (1.2\%); 7 products (39\%) had R-enantiomer exceeding the USP limit (1.5\%); 11 products (61\%) had total impurities exceeding the USP limit (2.5\%)

Proof that BE means TE: shown by Kesselheim et al. ${ }^{9}$ (JAMA, 2008) in a systematic review and metaanalysis of generic cardiovascular (CV) drugs which were bioequivalent to the innovator drugs (published in peer-reviewed journals between January 1984 and August 2008). CV drugs are critical use drugs, therefore require $\mathrm{BE}$ studies.

A total of 47 articles were reviewed, covering 9 subclasses of CV drugs, of which 38 articles (81\%) were randomized controlled trials (RCTs).
Clinical equivalence was noted in:

- 7 of 7 RCTs (100\%) of b-blockers

- 10 of 11 RCTs (91\%) of diuretics

- 5 of 7 RCTs (71\%) of calcium channel blockers

- 3 of 3 RCTs of antiplatelet agents

- $\quad 2$ of 2 RCTs of statins

- $\quad 1$ of 1 RCT of ACEIs

- 1 of 1 RCT of a-blockers

- 1 of 1 RCT of class 1 anti-arrhythmic agents

- 5 of 5 RCTs (100\%) of warfarin

Aggregate effect size $(n=837)$ was - 0.03 (95\% CI, - 0.15 to 0.08 ), indicating no evidence of superiority of innovator to generic drugs. Among 43 editorials, 23 (53\%) expressed a negative view of generic drug substitution.

Comparing generic and innovator drugs: a review of 12 years of BE data from the USFDA (from 1996 to 2007)..$^{10}$ From 2070 single-dose BE studies of orally administered generic drug products approved by the FDA (using from 12 to 170 subjects/study), the average difference between generic and innovator products: in $\mathrm{C}_{\max } 4.35 \%$, in AUC $3.56 \%$ (nearly $98 \%$ of the BE studies, the AUC differed by $<10 \%$ ). These results support the FDA's objective of approving generic drug formulations that are therapeutically equivalent to their innovator counterparts.

\section{Polymorphism of clopidogrel bisulfate ${ }^{4}$}

Polymorphism is the occurrence of different crystalline forms of the same drug substance. Two polymorphic forms of clopidogrel have been identified and designated as form 1 and form 2. The difference between the 2 crystal forms lies in the organization of the clopidogrel cations and sulfate anions.

Form 1 is a monoclinic space group and contains 2 crystallographically independent ion pairs in the asymmetric unit (irregular plates), and its melting point is $184^{\circ} \mathrm{C}$. Form 2 is an orthorhombic space group and contains one ion pair in the asymmetric unit. It is at least as stable as form 1 and it does not invert spontaneously to form 1. Form 2 bulk solid is more compact and much less electrostatic than form 1 . Form 2 exhibits a lower solubility than form 1 as a result of its greater thermodynamic stability, and its melting point is $176^{\circ} \mathrm{C}$.

Among 6 different polymorphic forms and an amorphous form of the drug identified, only forms 1 and 2 are used in pharmaceutical formulations. Form 1 and form 2 have the same indications. ${ }^{4}$

A review by USFDA concluded that pharmaceutical solid polymorphism has no relevance to the determination of drug substance "sameness" in ANDAs (Abbreviated New Drug Applications). Therefore it is allowed to use alternate polymorphic forms as long as the criteria of pharmaceutical equivalence and bioequivalent are met. ${ }^{7}$ 


\section{United States Patent: ${ }^{11,12}$}

Form 1: filed 1988, granted 1989

Form 2: filed 1999, granted 2002

\section{Indonesian Patent: ${ }^{13,14}$}

Form 1: filed 1988, granted 1997, expired 2008

Form 2: filed 1999, granted 2003, expired 2019

\section{A pivotal clinical trial of clopidogrel form-1: CAPRIE study (1996) ${ }^{15}$}

(Clopidogrel versus Aspirin in Patients at Risk of Ischemic Events). A total of 19,185 patients with atherosclerotic vascular disease, manifested as recent ischemic stroke, recent myocardial infarction and symptomatic peripheral arterial disease (more than 6,300 patients in each clinical subgroups) were randomized to receive clopidogrel $75 \mathrm{mg}$ once daily or aspirin $325 \mathrm{mg}$ once daily in a double-blind fashion. They were followed for 1 to 3 years (mean 1.91 years). The primary outcome was a composite of ischemic stroke, myocardial infarction and vascular death.

Table 1. Efficacy results of CAPRIE study (ITT analysis)

\begin{tabular}{|c|c|c|c|c|}
\hline & $\begin{array}{l}\text { 1ry outcome } \\
\text { No. of Events }\end{array}$ & $\begin{array}{l}\text { Event Rate } \\
\text { per year }\end{array}$ & $\begin{array}{l}\text { Relative-Risk } \\
\text { Reduction } \\
(95 \% \mathrm{CI})\end{array}$ & $\mathrm{p}$ \\
\hline Clopidogrel $(* n$ yrs = 17,636) & 939 & $5.32 \%$ & $8.7 \%$ & 0.043 \\
\hline Aspirin (n yrs = 17,519) & 1,021 & $5.83 \%$ & $(0.3-16.5)$ & \\
\hline
\end{tabular}

*Patient-years at risk for outcome

No major differences in terms of safety

\section{Clopidogrel resistance $e^{16-18}$}

It is defined as the failure of clopidogrel to achieve its platelet inhibition effect. Müller et al ${ }^{16}$ divided these patients into clopidogrel non-responders and semi-responders. Non-responders were defined by an inhibition of ADP ( 5 and $20 \mathrm{mMol} / \mathrm{L}$ ) induced platelet aggregation of $<10 \%$ compared to baseline values at 4 hours after clopidogrel intake. Semi-responders, when the inhibition was 10 to $29 \%$ of baseline. They found that $5 \%$ (ADP $5 \mathrm{mMol} / \mathrm{L}$ ) to $11 \%$ (ADP $20 \mathrm{mMol} / \mathrm{L}$ ) of the patients were non-responders, and 9 to $26 \%$ were semi-responders. Among the non-responders there were some patients who developed subacute stent thrombosis after PCI (percutaneous coronary intervention). This observation suggests that clopidogrel resistance may cause thromboischemic complications. ${ }^{16}$

According to Nguyen et al. ${ }^{17}$, current available data show that about 4 to $30 \%$ of patients treated with conventional doses of clopidogrel do not display adequate antiplatelet response at 24 hours after clopidogrel administration. Preliminary results seem to indicate that low antiplatelet effect of clopidogrel may lead to higher risk of developing cardiovascular events. ${ }^{18}$ However, the optimal level of clopidogrel-induced platelet inhibition that will correlate quantitatively with clopidogrel's ability to prevent atherothrombotic events is still lacking. ${ }^{17}$

The interpatient variability in clopidogrel response is multifactorial. It can be due to extrinsic and/or intrinsic mechanisms such as under-dosing, drug-drug interactions involving CYP3A4 and/or CYP2C19, or genetic polymorphisms of the $\mathrm{P} 2 \mathrm{Y} 12$ receptor or CYP3A4 or CYP2C19. ${ }^{17}$

Presently, it is impossible to predict which patient will be resistant to clopidogrel. Unfortunately, there is currently no single and validated platelet function assay to measure clopidogrel antiplatelet effect. Therefore, it is not justified to routinely look for clopidogrel resistance in the clinical setting. At present, there is no proven therapy to overcome low responsiveness to clopidogrel, but recent clinical data favor increasing the loading dose of clopidogrel in patients undergoing PCI. ${ }^{17}$

Based on the above description, it can be summarized as follows: (1) Health care costs continue to increase, therefore substitution with cheaper generic copies is required. (2) BE study is required to show whether a generic copy can be interchangeable with the brand innovator product. (3) BE studies are mainly required for generic/copy products with narrow margin of safety or critical use drugs. (4) The comparator/reference product is normally the innovator product. (5) BE studies are conducted with a randomized cross-over design, in accordance with GCP and GLP principles. (6) $\mathrm{BE}$ studies of clopidogrel generics were performed by pharmacokinetic method based on the measurement of clopidogrel parent compound using non-enantiospecific assay. (7) The clopidogrel generic products in Indonesia contain API clopidogrel form 1 that complies with USP 30, 1997 requirements: the R-enantiomer content is not more than $1 \%$ and the hydrolysis product is not more than $0.2 \%$. (8) The generic copy products of clopidogrel in Indonesia have been shown to be BE to the innovator product Plavix ${ }^{\circledR}$. (9) Clopidogrel form 1 and form 2 have the same indications. (10)At least one pivotal study of clopidogrel, CAPRIE, used clopidogrel form 1. CAPRIE documented that clopidogrel was superior to aspirin in reducing ischemic events. (11) A meta-analysis of generic $\mathrm{CV}$ drugs which are $\mathrm{BE}$ to the innovator drugs showed clinical equivalence of the generic drugs to the innovator drugs. (12)An atherothrombotic event may be associated with clopidogrel resistance, which occur in about 4 to $30 \%$ of patients treated with conventional doses of clopidogrel. 


\section{REFERENCES}

1. NFDC (National Food and Drug Control). Guideline for bioequivalent study. NFDC of Indonesia, 2004.

2. Plosker GL, Lyseng-Williamson KA. Clopidogrel: a review of its use in the prevention of thrombosis. Drugs. 2007; 67(4):613-46.

3. USFDA. Guideline for bioequivalent study. 2003.

4. Bousquet A, Castro B, Saint-Germain J. Polymorphic form of clopidogrel hydrogen sulphate. US Patent 6504030. Jan 07,2003. Ref. Chem Abstr. 2000;132:54841n.

5. USP 30, 2007.p. 1802-5.

6. Certificate of analysis of Clopidogrel bisulfate (Form 1). Pharmaceutical ingredient - USP verified.

7. Raw AS, Furness MS, Gill DS, Adams RC, Holcombe Jr FO, Yu LX. Regulatory considerations of pharmaceutical solid polymorphism in Abbreviated New Drug Applications (ANDAs). Adv Drug Deliv Rev. 2004;56:397-414.

8. Gomez Y, Adams E, Hoogmartens J. Analysis of purity in 19 drug product tablets containing clopidogrel: 18 copies versus the original brand. J Pharmaceut Biomed Anal. 2004;34:341-8

9. Kesselheim AS, Misono AS, Lee JL, Stedman MR, Brookhart MA, Choudhry NK, et al. Clinical equivalence of generic and brand-name drugs used in cardiovascular disease: a systematic review and meta-analysis. JAMA. 2008; 300(21):2514-26.

10. Davit BM, Nwakama PE, Buehler GJ, Conner DP, Haidar $\mathrm{SH}$, Patel DT, et al. Comparing generic and innovator drugs: a review of 12 years of bioequivalent data from the USFDA. Ann Pharmacother. 2009;43(10):1583-97.
11. Badorc A, Frehel D. Dextro-rotatory enantiomer of methyl alpha-5 (4,5,6,7-tetrahydro (3,2-c) thienopyridyl (2-chlorophenyl)-acetate and the pharmaceutical compositions containing it. US Patent: 4847265. July 11, 1989.

12. Bousquet A, Castro B, Saint-Germain J. Polymorphic clopidogrel hydrogen sulphate form. US Patent. Patent No.: US 6,429,210 B1. Aug 06, 2002.

13. Badorc A, Frehel D. Dextro-rotatory enantiomer of methyl alpha-5 (4,5,6,7-tetrahydro (3,2-c) thienopyridyl (2-chlorophenyl)-acetate and the pharmaceutical compositions containing it. Indonesian Patent: ID 0001 536. May 1, 1997.

14. Bousquet A, Castro B, Saint-Germain J. Polymorphic clopidogrel hydrogen sulphate form. Indonesian Patent. Patent No.: ID 0001 449. July 25, 2003.

15. CAPRIE Steering Committee. A randomized, blinded, trial of clopidogrel versus aspirin in patients at risk of ischemic events (CAPRIE). Lancet. 1996; 348:1329-39.

16. Müller I, Besta F, Schulz C, Massberg S, Schönig A, Gawaz M. Prevalence of clopidogrel non- responders among patients with stable angina pectoris scheduled for elective coronary stent placement. Thromb Haemost. 2003;89:783-7.

17. Nguyen TA, Diodati JG, Pharand C. Resistance to clopidogrel: a review of evidence. J Am Coll Cardiol. 2005;45:1157-64.

18. Matetzky S, Shenkman B, Guetta V, Shechter M, Bienart $\mathrm{R}$, Goldenberg J, et al. Clopidogrel resistance is associated with increased risk of recurrent atherothrombotic events in patients with acute myocardial infarction. Circulation. 2004;109:3171-5. 